\title{
The labor market for older workers in Germany
}

\author{
Viktor Steiner $^{1}$
}

Accepted: 21 February 2017 / Published online: 9 March 2017

(c) The Author(s) 2017. This article is available at SpringerLink with Open Access.

\begin{abstract}
The paper describes labor market developments for older workers in Germany in recent years. It provides a a summary of the main changes in labor market and pension policies in Germany which might have contributed to these developments. The main part of the paper offers, on the basis of micro data from the Socioeconomic Panel (SOEP), empirical evidence on changes in employment and longterm unemployment, early retirement as well as relative wages by age for Germany in the period 2000-2014. Based on this empirical analysis, some implications for labor market policies are discussed.
\end{abstract}

\section{Der Arbeitsmarkt für ältere Arbeitnehmer in Deutschland}

Zusammenfassung In diesem Beitrag wird die Arbeitsmarktentwicklung für ältere Arbeitnehmer in Deutschland in den letzten Jahren beschrieben. Der Beitrag fasst wichtige Änderungen in der Arbeitsmarkt- und Rentenpolitik in Deutschland zusammen, die diese Entwicklung beeinflusst haben könnten. Im Hauptteil des Beitrags werden die Ergebnisse einer empirischen Analyse auf Basis des Sozioökonomischen Panels (SOEP) zur Entwicklung der Beschäftigung, langfristigen Arbeitslosigkeit, Frühverrentung und der Lohnentwicklung nach Altersgruppen im Zeitraum 2000-2014 präsentiert. Auf Basis dieser empirischen Ana-

Viktor Steiner

viktor.steiner@fu-berlin.de

1 Fachbereich Wirtschaftswissenschaft, Empirische Wirtschaftsforschung und Wirtschaftspolitik, Freie Universität Berlin, Boltzmannstr. 20, 14195 Berlin, Germany lyse werden Implikationen für die Arbeitsmarktpolitik diskutiert.

\section{Introduction}

Until recently, policy discussions in Germany have been dominated by concerns about high unemployment, employment uncertainty, increasing earnings inequality, and the long-term impact of these developments on the public pension system. In particular, long-term unemployment and early retirement of older workers have been one of the more problematic features of the German market. However, in the wake of the severe economic recession in 2009, the performance of the German labor market improved significantly with increasing employment and decreasing unemployment rates. An important feature of the "German employment miracle" has been the substantial improvement of the labor market situation of older workers, which is the topic of the present study.

Between 2000 and 2014 the overall German employment rate for the age group 25-65 years, as measured from survey data on an individual's labor force status, has increased by about 10 percentage points from $70 \%$ to $80 \%$. Furthermore, starting around 2005 the average unemployment rate has been steadily declining from about $10 \%$ in 2005 to about $6 \%$ in 2014 . Especially after the economic and financial crises in 2009/10, the labor market has, on average, developed more favorably in Germany than in most other EU countries.

As shown by Fig. 1, the favorable labor market developments in Germany after the crises are driven by strongly increasing employment rates and declining unemployment rates of older workers. Starting from a very low level in the early 2000's, the employment rate of people in the age 

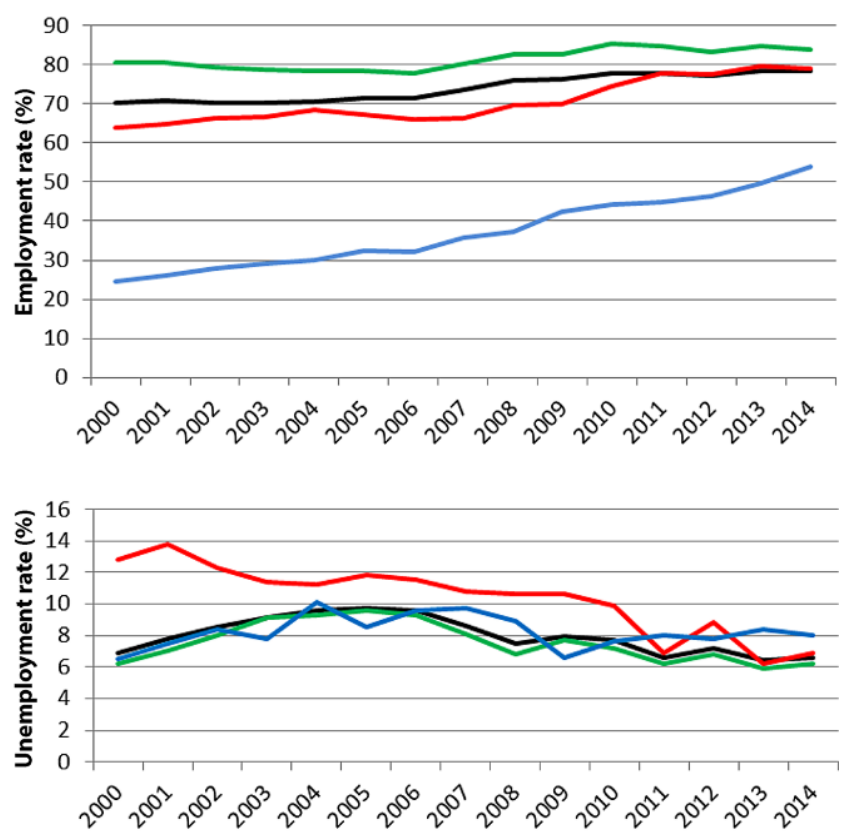

$-24<$ Age $<=65-24<$ Age $<55$
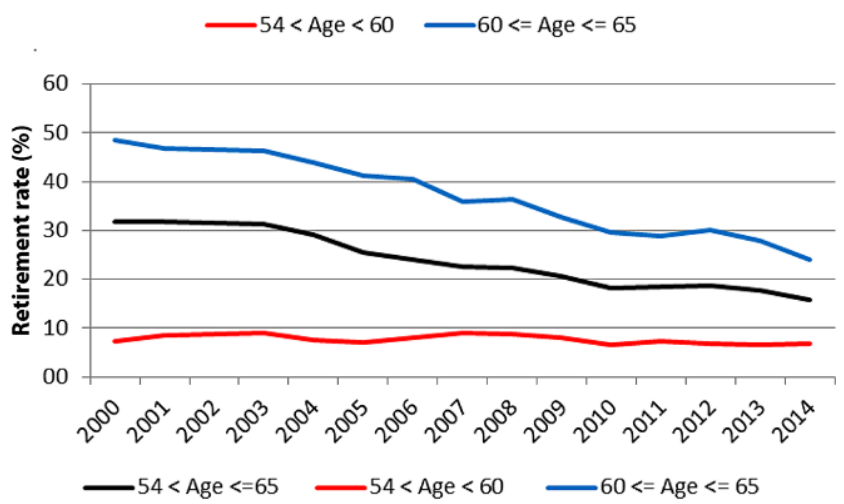

Fig. 1 Employment, unemployment, and retirement in Germany, 2000-2014. (Notes: Employment rates refer to answers of people aged 25 to 65 years to their current labor force status. Retirement rates refer to people aged 55 to 65 years. Data are weighted using SOEP weighting factors. Source: SOEP 2000-2014, own calculations)

group $60-65$ years doubled and reached more than $50 \%$ by 2014. The employment rate of people aged between 55 and 59 years also increased substantially, especially after 2009, while the employment rate of younger people stabilized at a relatively high level of about $80 \%$ since then. ${ }^{1}$ Starting at a double-digit level, the unemployment rate of people aged 60 years or older decreased more or less steadily since the early 2000's and converged to the average rate of about $6 \%$ by 2014 . For the total working-age population, the unemployment rate increased until 2005 to a level of about $10 \%$

\footnotetext{
1 The employment rate of workers aged 55-59 years started to increase already in the mid-1990s, after it had dropped in the wake of German unification in the early 1990s. To account for these transitional effects, I choose 2000 as the starting year for the analysis in this paper.
}

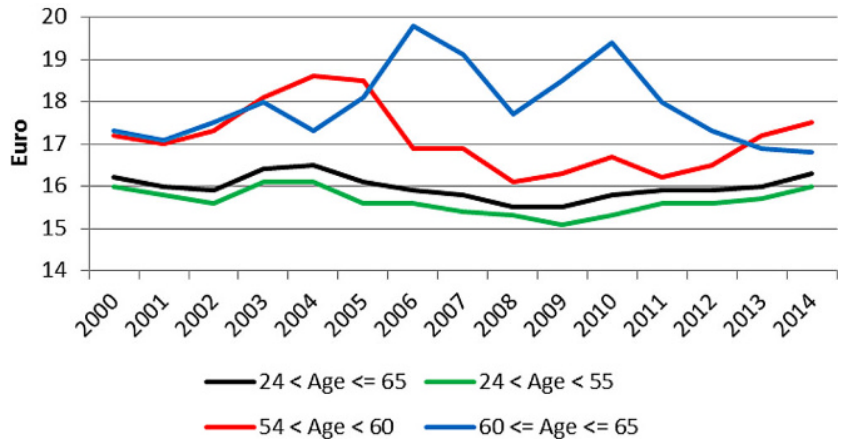

Fig. 2 Real hourly wages in Germany, 2000-2014. (Notes: Real hourly wages are derived using SOEP generated information on individual annual earnings and actual working hours. Real hourly wages smaller than 1.5 and larger than $150 €$ are not included. The self-employed are excluded. Data are weighted using SOEP weighting factors. Source: SOEP 2000-2014, own calculations)

and then declined more or less steadily with only a slight increase in the wake of the economic recession in 2009. By 2014 , the average unemployment rate of $6 \%$ has reached the same level as at the beginning of the observation period.

Another important feature of labor market developments in Germany is the evolution of real hourly wages which have, on average, changed little since 2000 (Fig. 2). Except for the oldest age group, average real wages declined for several years before the recession in 2009 and increased slightly since then. For employees in the oldest age group real wages increased between 2005 and 2010 but declined in recent years. Given that the employment rate of older people has changed substantially in the observation period, it seems likely that the observed wage changes for this group are driven by selection effects: The average wage could have been driven down by older people with a relatively low level of productivity who remained long-term unemployment or retired early in previous periods and now remain employed until the statutory retirement age.

The factors which might have contributed to the described labor market development remain controversial. As discussed by Dietz and Walwei (2011), labor market reforms as well as a series of pension reforms enacted in the late 1990's and early 2000's (see Chap. 2) may have been of particular importance for explaining to higher employment and lower unemployment rates of older people in Germany. As in other EU member states (see, e. g., Toft and Whitehouse 2016), the pension reforms were clearly targeted at increasing the effective early retirement age. The reform of the unemployment compensation system was mainly intended to increase work incentives in general, and not especially targeted at older workers, but may still have had relatively strong effects on them. The same can be said about the extension of earnings subsidies for so-called "marginal jobs" that are completely or partially exempted from social security contributions on the part of workers. Other labor 
market reforms were targeted at increasing employment opportunities of older people with little earnings potential.

A couple of studies have estimated the partial effects of some of these reforms. ${ }^{2}$ Taken together, these studies seem to suggest that recent labor market and pension reforms may have contributed to the increase in employment and the reduction in unemployment of older workers. Although there seems to be no quantitative assessment on the overall economic effects of these reforms on older workers, their overall direct contribution to the substantial employment increase of older workers is likely to have been relatively small. Although potential wage determinants have been empirically analyzed for Germany in various recent studies (see Möller and Hutter 2011), there seems to be little empirical research yet on the effects of policy reforms on wages and, in particular, their indirect effects on employment and unemployment among older workers. ${ }^{3}$

This paper aims at establishing important stylized facts about the development of the labor market for older workers in Germany in recent years. The focus of this descriptive analysis is on identifying age effects in changes of various labor market outcome variables between 2000 and 2014 . These include various employment and unemployment indicators as well as the real hourly wage, all measured at the individual level using data from the Socioeconomic Panel (SOEP) for the period 2000-2014. To identify age effects, I estimate statistical models for the various labor market outcome indicators at the individual level conditional on the set of usual control variables. To account for the importance of gender and the still existing large differences in most of these indicators between east and west Germany, the estimations are differentiated by gender and region.

\footnotetext{
2 There is a couple of evaluation studies on the effects of previous unemployment benefit reforms which raised maximum benefit-entitlement periods for older workers (see, e. g., Steiner 1997; Fitzenberger and Wilke 2010). These ex-post evaluations studies treat unemployment benefit reforms as "natural experiments", the results of which are specific to these particular reforms and cannot be generalized to the more recent reforms under consideration here. There are also a number of evaluation studies on the employment and wage effects of recent labor market programs for Germany which are not particularly targeted at older people, although they may have had disproportionate effects on them (for summaries see, e. g., Fitzenberger 2009; Steiner 2009; Wolff and Stephan 2013). On recent labor market reforms disproportionally affecting older workers, see Ammermüller et al. (2006), Steiner and Schmitz (2007), Dlugosz et al. (2014); on pension reform, see, e. g., Börsch-Supan and Berkel (2004) and Hanel (2012).

3 Arent and Nagl (2013) attempt to identify the wage effects of one particular component of the German labor market reforms introduced in 2005, namely the "unemployment benefit II" ("Hartz IV") reform, by the difference in the trend in wages after and before the reform. There is, of course, no reason to believe that the overall time trend in wages after the reform would have been, in the absence of the reform, the same as before the reform. See Ludsteck and Seth (2014) for a critique of this and other assumptions of the study.
}

Estimation results are best interpreted as descriptive, as it is generally not possible to distinguish the "causal" effects of the labor market and pension reforms described above, demographic changes unrelated to these reforms, and age specific labor market effects of the business cycle and the crises of 2009/2010. Still, it seems useful to provide a brief summyry of the most important changes in labor market and pension policies in the observation period that might have contributed to these developments (Sect. 2). Chap. 3 presents estimation results on age effects in employment and unemployment changes, while Sect. 4 looks at early retirement and Sect. 5 on the development of real hourly wages by age group. Based on this empirical analysis, some implications for labor market policies are discussed in the concluding Chap. 6.

\section{Recent labor market and pension reforms}

There have been a number of labor market and pension reforms in Germany which may have had quantitatively important effects on labor market outcomes of older people in the observation period of this study. These reforms, as far as they are relevant for the subsequent empirical analysis, are summarized in Table 1 and briefly discussed below. I do not consider all policy changes which, although not specifically targeted at older people, may nevertheless have disproportionally affected this group. ${ }^{4}$

\subsection{Labor market reforms}

One important aim of the labor market reforms introduced in Germany in 2003-2006 under the name "Agenda 2010" or "Hartz reforms" ${ }^{5}$ was to increase work incentives for people with low earnings potential. Probably the most controversial reform introduced to achieve this aim concerns the unemployment compensation system. The reform was partly a reaction to the perceived disincentive problems related to two features of the previous system: First, the rather long maximum unemployment benefit entitlement periods

\footnotetext{
${ }^{4}$ Examples are traditional instruments of "active" labor market policy such as training programs and public-works programs subsidized by the Federal Labor Agency (see, e. g., Caliendo and Steiner 2005) as well as other publicly subsidized labor market programs such as marginal employment (so-called "mini-jobs") or start-up subsidies for unemployed people becoming self-employed, which were introduced or amended in the wake of the labor market reforms 2003-2006 (see, e. g., Fitzenberger 2009; Steiner 2009). Employment protection regulation which was also adapted in the wake of these reforms, is another example which, although not specifically targeted at older workers, might well have disproportionally affected this group (see, e.g., Jahn and Walwei 2003).

5 Named after the chairman of the commission that proposed the reform package.
} 
Table 1 Recent changes in labor market policies affecting older workers and public pension regulations in Germany

\section{Unemployment compensation \\ 2004 Lower duration of unemployment benefit I (UB I) for older workers (from a maximum of 32 months to a maximum of 18 months) and tightening of entitlement criteria regarding an individual's previous employment record; became first effective in 2006}

2005 Integration of social assistance and unemployment assistance into the new means-tested unemployment benefit II which replaces social assistance for all "employable" people

2008 Longer duration of unemployment benefits for older workers (from a maximum of 18 months to a maximum of 24 months)

Special labor market programs for older workers

2003 In-work benefits (Entgeltsicherung) to unemployed people aged 50 years and older who are entitled to UB I

2003 Reduced social security contributions on "marginal" employment ("mini-" and "midi-jobs")

2004 Temporary wage subsidies (Eingliederungszuschuss) to firms employing people with severe placement difficulties including old age; integration of special subsidy for older workers into general temporary wage subsidy for "hard-toplace" people

2007 Re-introduction of a special subsidy for unemployed people aged 50 years and older and introduction of a wage-subsidy voucher for older people

Reforms of public pension regulations

1992 Introduction of deduction factors for early retirement $(0.3 \%$ per month before the legal retirement age), fully phased in by 1999 for young birth cohorts

1994 Lengthening of regulation which imply that unemployed being 58 or older have not to be at the disposal of unemployment agencies and are not counted as unemployed (until 2000)

1997 Raising of retirement age for long-term insured from 63 to 65 years (stepwise 2000 until 2001) and for women from 60 to 65 years (stepwise 2000 until 2004)

1999 Raising of retirement age for disabled (stepwise beginning in 2000)

2000 Lengthening of regulation which imply that unemployed being 58 or older have not to be at the disposal of unemployed agencies and are not counted as unemployed (until 2005)

2001 Reform of pensions for persons who are not capable for work

Introduction of subsidy of a supplementary capital-based private pension ("Riesterrente")

2005 Lengthening of regulation which imply that unemployed being 58 or older have not to be at the disposal of unemployed agencies and are not counted as unemployed (until 2007)

2008 Raising of general retirement age from 65 to 67 years (stepwise from 2012 until 2029)

2009 End of public subsidies for partial retirement schemes

2014 Early retirement at 63 for long-term insured people without pension deductions

Notes: The dates refer to the year the respective regulations became law, parentheses contain the phasing-in periods of reforms, for more details see text

Source: Adapted from Dietz and Walwei (2011) especially for older workers and, secondly, the generally unlimited eligibility for means-tested unemployment assistance after the expiration of the entitlement to unemployment benefit. Both of these regulations were changed by the recent reform, and the new rules became effective in 2005 and 2006, respectively. In particular, maximum entitlement periods for unemployment benefits, now termed unemployment benefit I (UB I), were substantially reduced, especially for the older unemployed from a maximum of 32 months to 18 months. However, this reduction was partly undone only two years after it became effective; already in 2008 the maximum UB I entitlement-period for older workers was increased from 18 to 24 months. The change of unemployment assistance into unemployment benefit II (UB II) for "employable" people defined as being able to work at least $3 \mathrm{~h}$ a day implied a tighter means test and, depending on previous earnings, possibly a reduced level of benefits. For older workers with relatively high earnings in their last job this could mean a substantial reduction in means-tested transfers, because UB II is no longer related to previous earnings as unemployment assistance was, but only covers the social minimum in case the now somewhat more stringent means test concerning household income and wealth is passed.

A labor market reform not specifically targeted at older workers, which may nevertheless have affected their employment and unemployment situation disproportionally is the extension of the subsidization of so-called "marginal" jobs ("mini" and "midi"-jobs; geringfügige Beschäftigung) that are completely or partially exempted from social security contributions on the employer side. This part was implemented at the beginning of the "Hartz" reforms in 2003 and increased work incentives especially for people who are not eligible to means-tested unemployment compensation and hold jobs with a small number of hours and low earnings, for example people on early retirement (see, e. g., Steiner and Wrohlich 2005).

Labor market programs specifically targeted at older workers include in-work benefits (Entgeltsicherung) and temporary wage subsidies (Eingliederungszuschuss). Inwork benefits are paid to unemployed people aged 50 years and older who are entitled to UB I instead of this social insurance payment (see Dietz et al. 2011). The program was introduced in 2003 and prolonged twice until 2011. The subsidy is paid for up to two years and covers $50 \%$ of the difference of an individual's net earnings in the previous and the new job in the first year, and $30 \%$ of this difference in the second year. Temporary wage subsidies (Eingliederungszuschuss) are paid to firms employing people with severe placement difficulties, of which old age is considered to be one (see Ruppe and Stephan 2009). The subsidy amounts, on average, to $50 \%$ of the gross wage including employers' social security contributions and is 
usually paid for a period of up to 24 months. They have existed in Germany already before the recent reform but have been slightly adjusted for older workers. In 2004 the subsidy for older workers was integrated into a general temporary wage subsidy for "hard-to-place" people; however, already in 2007 a special subsidy for unemployed people aged 50 years and older was re-introduced. For older workers the subsidy may be paid for a maximum duration of 36 months on a declining scale. As on alternative to this special subsidy, a voucher was introduced which can be redeemed by firms that hire unemployed people aged 50 years or older. As reported by Dietz and Walwei (2011) these instruments have not been widely used, however.

\subsection{Pension reforms}

There have been a number of important pension reforms in Germany in the 1990's which became only fully effective about a decade later due to the long transition period (see the summary in Dietz and Walwei 2011, Table 2). Among several other important changes, this reform introduced deduction factors for early retirement $(0.3 \%$ per month before the legal retirement age). Another reform in 1994 concerned a special regulation for unemployed people aged 58 years or older who were no longer counted as unemployed if they agreed to retire at the earliest possible early retirement age, which was still 60 years at that time. This regulation, known as the "58-years rule" was prolonged in 2000 but eventually abandoned in 2005 . Also in 1994, the legal retirement age for unemployed workers or for persons after partial retirement was raised from 63 to 65 years, where this change became only effective in a stepwise fashion at the beginning of the next decade. Public subsidies for partial retirement schemes ended in 2009. In 1997, the retirement age for long-term insured people was raised from 63 to 65 years and for women from 60 to 65 years with stepwise implementation between, respectively, 2000 to 2001 and 2000 to 2004. In general, early retirement without reductions of old-age pensions is no longer possible, with one exception: In 2014 a new regulation introduced the possibility of early retirement at the age of 63 without pension deductions for long-time (45 years) insured people.

For disabled people, the retirement age was raised from 60 to 63 years in a stepwise fashion beginning in 2000. During the transition period, early retirement was still possible, but the pension was cut by $0.3 \%$ per month. Also from 2000 on, early retirement for (older) people who cannot continue working in their occupation for health-related reasons ("Berufsunfähigkeitsrente"), where the labor market situation was taken into account, was abolished and inte-

Table 2 Employment probabilities 2000-2014, average marginal effects

\begin{tabular}{|c|c|c|c|c|c|c|c|c|}
\hline & \multicolumn{4}{|l|}{ Men } & \multicolumn{4}{|c|}{ Women } \\
\hline & \multicolumn{2}{|c|}{ West Germany } & \multicolumn{2}{|c|}{ East Germany } & \multicolumn{2}{|c|}{ West Germany } & \multicolumn{2}{|c|}{ East Germany } \\
\hline & AME & se & AME & se & AME & se & AME & se \\
\hline \multicolumn{9}{|l|}{ Full-time Employment } \\
\hline Year2007-8 & -3.14 & 0.88 & -1.92 & 1.56 & -1.34 & 0.71 & -1.97 & 1.30 \\
\hline Year2013-14 & -8.46 & 0.92 & -3.08 & 1.65 & -2.39 & 0.75 & -1.16 & 1.44 \\
\hline Age55-59 & 16.28 & 1.96 & 9.27 & 3.11 & 2.54 & 1.76 & 6.72 & 2.78 \\
\hline Age 55-59 × year2007-8 & 4.75 & 3.27 & 6.09 & 5.11 & 2.47 & 2.59 & 0.92 & 4.48 \\
\hline Age55-59 × year2013-14 & 16.22 & 3.03 & 13.58 & 5.04 & 4.84 & 2.43 & 9.97 & 4.17 \\
\hline Age60-65 & -17.78 & 1.93 & -21.64 & 3.45 & -23.41 & 2.56 & -33.56 & 4.09 \\
\hline Aged60-65× year2007-8 & 10.51 & 3.04 & 7.46 & 5.46 & 10.54 & 3.50 & 12.30 & 5.84 \\
\hline Aged60-65× year2013-14 & 25.83 & 2.78 & 29.25 & 4.96 & 18.40 & 3.17 & 29.01 & 5.38 \\
\hline \multicolumn{9}{|l|}{ Part-time Employment } \\
\hline Year2007-8 & -0.89 & 0.59 & -0.53 & 1.02 & 3.02 & 0.75 & 2.57 & 1.26 \\
\hline Year2013-14 & 0.11 & 0.54 & 2.02 & 1.11 & 3.76 & 0.74 & 5.63 & 1.27 \\
\hline Age55-59 & 0.61 & 1.24 & 3.40 & 2.28 & 8.38 & 1.79 & 6.05 & 2.87 \\
\hline Age $55-59 \times$ year $2007-8$ & 2.41 & 2.03 & 1.16 & 3.39 & 0.97 & 2.62 & 1.51 & 4.12 \\
\hline Age 55-59 × year2013-14 & -0.74 & 1.84 & -1.56 & 3.27 & 7.74 & 2.55 & 0.47 & 3.76 \\
\hline Age60-65 & -2.04 & 1.25 & 1.62 & 2.18 & -7.54 & 1.97 & -10.00 & 3.27 \\
\hline Aged60-65 × year2007-8 & 4.08 & 1.85 & -0.20 & 3.57 & 5.25 & 2.95 & 10.60 & 4.64 \\
\hline Aged60-65 × year2013-14 & 6.13 & 1.74 & 0.39 & 2.81 & 13.95 & 2.70 & 16.09 & 4.16 \\
\hline
\end{tabular}

Notes: AME - marginal effect on probability (in percent) from pooled logit estimates for the years 2000/01, 2007/08, and 2013/14; standard errors (se) are clustered to account for the panel structure of the SOEP estimation sample. The probability models are estimated separately by gender and region and include dummies for an individual's education/vocational qualifications, health status, nationality, marital status, children (younger than 7 and 14 years, respectively), other household income and its square as additional control variables

Source: Own calculations based on SOEP data 2000-2014 
grated into a categorical, more restrictive disability pension ("Erwerbsminderungsrente").

Starting at the beginning of 2012, the statutory retirement age is increasing in a stepwise fashion from 65 to 67 years, where the adjustment to a higher statutory retirement age starts with an additional month for people born in 1947 and is completed at around 2030, when people born in 1964 or later can only retire at the age of 67 without pension deductions.

\section{Employment and unemployment}

This section provides a detailed empirical analysis of the developments of employment and unemployment by age group in the period 2000-2014 on the basis of micro data from the German Socioeconomic Panel (SOEP). The SOEP is a representative survey of the German population providing panel information on employment patterns, wages, incomes, personal characteristics, and household structure (see www.diw/soep). Compared to other micro data sets for Germany it has the advantage of a panel and that it contains detailed information on labor market variables, including individual earnings and working hours. I use SOEP data for the following analysis because part of it requires panel data and information on hourly wages, which alternative data sets do not provide. ${ }^{6}$ The disadvantage of the SOEP is its limited sample size, which renders estimation of population statistics for small groups somewhat imprecise. To increase sample size, I therefore aggregate observations of two adjacent years In the estimations below. ${ }^{7}$

The aim of the following analysis is to estimate changes in various labor market indicators for various age groups over time, where I distinguish these groups by gender and region (east and west Germany). To describe labor market developments in the period before and after the 2009 recession, I split the observation period into two sub-periods: the first covers the years 2000-001 to 2007-08, and the second the period since then up to 2013-14. I will present the estimations for the two age groups 55-59 years and 60-65 years, respectively, where people aged $25-54$ years serve as the reference group. I do not include people younger than 25 years in the analysis because a large share of them have not completed their vocational education earlier. The regional and gender differentiation seems es-

\footnotetext{
${ }^{6}$ The Labor Force Survey ("Mikrozensus") of the Federal Statistical Office has no panel structure and does not provide information on earnings at the individual level. The Employment Statistics of the Federal Labor Agency has only limited information on working hours and no information on household structure. There is also the problem that for a very large share of all cases information on the education variable is missing in this latter data set. .

${ }^{7}$ I thank one of the referees for this suggestion.
}

pecially important for the analysis of labor market of older workers, where gender differences persist between east and west Germany even more than 25 years after unification.

I present estimation results from various statistical models of employment and unemployment focusing on changes among older workers before and after the economic and financial crises. Given the descriptive nature of these estimates, I use weighting factors in all estimations to represent population statistics. The estimates are conditional on other potential determinants of labor market outcomes at the individual level. These include an individual's level of education/vocational qualification, nationality, health status, marital status, the presence of children in the household, and other household income. The level of education/vocational qualification is differentiated between low, medium and higher, where medium mainly consists of vocational education and special types of secondary schooling, while higher consists of university education and polytechnical schools ("Fachhochschule"); master craftsmen who gained highly specialized vocational qualifications after apprenticeship training are also included in this latter group.

\subsection{Employment}

Since there has been much concern in public policy debates about the increasing importance of "non-standard" employment, the following analysis distinguishes between full-time and part-time employment. Although the notion of "non-standard" employment is certainly somewhat broader than part-time employment, it includes an important component of it, namely "marginal employment" which is not or only partially subject to social security contributions (see Sect. 2 above). Part-time employment has also gained increasing importance among women in east Germany and for men in partial retirement in both regions. In contrast, self-employment rates have changed little within the observation period and have remained, on average, below $10 \%$ of the workforce. Self-employed people are included in the following analysis without further explicit differentiation between full-time and part-time employment.

Table 2 reports average marginal (partial) (AME) of year and age group interactions derived from logit employment models and their standard errors estimated separately by gender and region on pooled SOEP panel data from 2000-2014, where the year effects refer to the observation years $2007-8$ and 2013-14, respectively, relative to the base period 2000-01. AME give the average percentage change of the employment probability of the respective variable relative to the base category. Standard errors are based on clustering observations by individual to account for the panel structure of the SOEP estimation sample. Estimation results for full-time employment are summarized in 
the upper part of the table, those for part-time employment in the lower part.

The interaction terms identify the marginal effects of changes of the age effects on the employment probabilities within the observation period. For example, the AME estimated for west German men in the oldest age group and the second time period (age55-59 $\times$ year2013-14) implies that full-time employment within this group increased, on average, by about 26 percentage points since $2000-01$ relative to the change in the reference group of people aged 25-54 years; since full-time employment in the youngest age group declined by about 8 percentage points in this period, the estimates imply an increase in the full-time employment rate of the oldest relative to the youngest age group by about 18 percentage points. The level of the employment rate for a specific age group at the end of the observation period can be obtained by adding the respective marginal age and interaction effects to the average employment rates for the reference group of younger people in 2000-01, which are reported in Table 7 in the Appendix. For the oldest age group this would yield an average fulltime employment rate of about $80 \%$ at the end of the observation period.

For a given age group, the difference of the AME of age group and year interaction terms shows the employment change that occurred between 2007-08 and 2013-14 relative to the reference age group, whereas the absolute employment change is obtained by deducting the difference of the year effects which refer to the reference age group. Thus, while full-time employment of younger men decreased by about 5 percentage points in the period between 2007-08 and 2013-14, it increased by about 6.5 percentage points for men in the age group 55-59 years in this period. While full-time employment has been decreasing for the younger age groups (25-54 years) over the whole observation period, it has been increasing substantially in the older age groups, in particular people aged above 60 years in the second sub-period. In West Germany, the full-time employment rate of men aged 60-65 years increased by about 25 percentage points between 2000-01 and $2013-14$, and by almost 10 percentage points since 2007-08. Amounting to almost $30 \%$, the increase in fulltime employment in this period has been even stronger for men in East Germany. In this period, the full-time employment rate of men has also substantially increased in the age group 55-59 years. Also, the female full-time employment rate increased substantially in the oldest age group, in particular in east Germany where the increase amounted to almost 30 percentage points between 2000-01 and 2013-14, with about two thirds of this increase occurring since 2007-08. In west Germany, the full-time employment rate of women in this age group increased by about 20 percentage point in the whole observation period.
As shown in the lower part of Table 2, the increase in female full-time employment rates in the older age groups was accompanied by substantial increases in the parttime employment rates in both west and east Germany. These increases were substantially larger than for women aged $25-54$, as shown by the pure time effects in the table which refer to the youngest age group. The increase in part-time employment among older women was particularly strong in both regions in the second period amounting to about 14 percentage points in the west and 16 percentage points in the east. Given the already quite high level of female part-time employment rates in west Germany (see Table 7), its substantial increase over the whole period seems even more remarkable than the somewhat larger increase estimated for women in the east where part-time employment was at a relatively low level at the beginning of the observation period. For men aged $60-65$, the relatively low part-time employment rate has increased by about 6 percentage points since 2000-01 in west Germany, while no significant effects can be observed among men in east Germany. Estimated changes in part-time employment rates of men aged 25-54 years as well as time effects for the age group 55-65 are not statistically significant.

While the increase in part-time employment among older men in west Germany and older women in both regions may be related to restrictions on early retirement and the labor market reforms in the observation period, as described in Sect. 2, it is not clear why this apparently did not affect part-time employment of older men in east Germany. To some extent, this may be related to the stronger increase in male full-time employment in east compared to west Germany. Another factor may be related to the increase in unemployment among older east German men, as described below.

\subsection{Unemployment}

The labor force status question in the SOEP referring to the month before the survey month is used to infer an individual's unemployment status. This unemployment measure resembles more the one derived from national statistics on registered unemployment than the internationally comparable concept based on self-assessed job searching activities. In fact, the unemployment rate calculated from SOEP date is very similar to the one calculated from the national statistics (see Fig. 1).

I estimate similar logit models of individual unemployment probabilities as in the previous section, again focusing on changes among older workers before and after the economic and financial crises. Except for other household income, the logit models include the same control variables as for the employment model above. Other household income is not included as a control variable here, because means- 
Table 3 Unemployment probabilities 2000-2014, average marginal effects

\begin{tabular}{|c|c|c|c|c|c|c|c|c|}
\hline & \multicolumn{4}{|l|}{ Men } & \multicolumn{4}{|c|}{ Women } \\
\hline & \multicolumn{2}{|c|}{ West Germany } & \multicolumn{2}{|c|}{ East Germany } & \multicolumn{2}{|c|}{ West Germany } & \multicolumn{2}{|c|}{ East Germany } \\
\hline & AME & se & AME & se & AME & se & AME & se \\
\hline Year2007-8 & 0.4 & 0.6 & -1.4 & 1.5 & 1.3 & 0.5 & -2.8 & 1.4 \\
\hline Year2013-14 & -0.2 & 0.7 & -4.2 & 1.7 & 0.0 & 0.6 & -8.7 & 1.6 \\
\hline Age 55-59 & 5.0 & 0.9 & 9.5 & 2.3 & 3.5 & 0.9 & 7.0 & 1.9 \\
\hline Age 55-59 × year2007-8 & -2.0 & 1.4 & -2.3 & 3.6 & -3.1 & 1.4 & -0.2 & 3.2 \\
\hline Age55-59 × year2013-14 & -3.6 & 1.6 & -7.7 & 3.9 & -4.5 & 1.4 & -3.9 & 3.3 \\
\hline Age60-65 & 2.7 & 0.8 & -0.7 & 2.2 & -0.8 & 1.0 & -10.9 & 2.2 \\
\hline Aged60-65 × year2007-8 & 1.4 & 1.3 & -0.5 & 3.4 & 1.7 & 1.4 & 3.0 & 3.6 \\
\hline Aged60-65 × year2013-14 & 0.1 & 1.4 & 5.2 & 3.4 & 2.0 & 1.4 & 12.9 & 4.0 \\
\hline
\end{tabular}

Notes: AME - marginal effect on probability (in percent) from pooled logit estimates for the years 2000/01, 2007/08, and 2013/14; standard errors (se) are clustered to account for the panel structure of the SOEP estimation sample. The probability models are estimated separately by gender and region and include dummy variables for an individual's education/vocational qualifications, health status, nationality, marital status, children (younger than 7 and 14 years, respectively), other household income and its square as additional control variables

Source: Own calculations based on SOEP data 2000-2014

tested transfers related to unemployment are allocated at the household level and cannot be assigned individually and deducted from total net household income. Estimated AME and their standard errors are reported in Table 3, the interpretation of AME of age group and year interactions is analogous to the one described for the employment probability models above.

While the unemployment probability for people aged 55-59 years has declined significantly in all groups between 2000-01 and 2013-14, the decline has been much more pronounced for both men and women in east Germany. Note that the unemployment probability has also declined substantially for younger people in east Germany, while no significant time trend for this age group could be detected in the west. In east Germany the substantial unemployment differentials between the older and younger men of almost 9 percentage points was virtually eliminated over the observation period. For older women, the AME effect estimated at -3.9 is not statistically significant from zero (estimated s.e. $=3.3$ ) and thus implies a similar decline of the unemployment rate as estimated for the younger age group, which amounts to more than 8 percentage points in the observation period. In west Germany, the initial unemployment differential between the older and younger age groups was also significantly reduced for both men and women by the end of the observation period.

For the oldest age group (60-65 years) age effects in unemployment rates have changed little for both men and women in west Germany within the observation period, whereas large and statistically significant increases in unemployment rates are estimated for east Germany. In particular, while the unemployment rate of younger women declined substantially in the observation period, the estimated AME for older women implies an increase in the unemployment rate by about 5 percentage points. Given the relatively low unemployment rate of older women in East Germany at the beginning of the observation period, these estimates imply that age differentials in female unemployment have been reduced in recent years, but remain substantial.

Age differences in current unemployment rates documented in Table 3 may not properly reflect the importance of long-term unemployment, especially for older workers. Long-term unemployment is usually defined by the share of people with interrupted unemployment durations in their current spells of more than one year. This definition misses the potential importance of brief but frequent unemployment spells which may accumulate to long-term unemployment over the lifecycle. To account for this, I use the cumulated duration of unemployment an individual has experienced since the age of 15 years as a measure of long-term unemployment. This variable is generated from retrospective SOEP data on time spent in various labor market states over the individual lifecycle. This measure also avoids the arbitrary choice of reference period and the left-censoring of unemployment durations.

To account for the large share of people who have not been unemployed at all over their lifecycle, I estimate tobit models with censoring at the value of zero of the cumulated unemployment duration variable separately by gender and region and the same control variables as in the unemployment probability models. Estimated AME for age and year effects and their interactions, which measure the change in the expectation of the cumulated unemployment durations in years (including zero unemployment durations), and their standard errors are reported in Table 4.

Long-term unemployment of people aged 25-54 years has increased by almost one year for men and women in east Germany, and by about four months in west Germany, where almost all of this increase took place until 2007-08. 
Table 4 Long-term unemployment, average marginal effects

\begin{tabular}{|c|c|c|c|c|c|c|c|c|}
\hline & \multicolumn{4}{|l|}{ Men } & \multicolumn{4}{|c|}{ Women } \\
\hline & \multicolumn{2}{|c|}{ West Germany } & \multicolumn{2}{|c|}{ East Germany } & \multicolumn{2}{|c|}{ West Germany } & \multicolumn{2}{|c|}{ East Germany } \\
\hline & AME & se & AME & se & AME & se & AME & $\mathrm{se}$ \\
\hline Year2007-8 & 5.4 & 0.5 & 9.4 & 1.2 & 5.9 & 0.5 & 10.2 & 1.3 \\
\hline Year2013-14 & 4.6 & 0.7 & 10.7 & 1.7 & 3.9 & 0.5 & 11.0 & 1.7 \\
\hline Age55-59 & 1.8 & 1.4 & 3.1 & 2.2 & -0.4 & 1.2 & 5.5 & 2.6 \\
\hline Age 55-59 × year2007-8 & -2.5 & 2.0 & -1.2 & 4.1 & -0.3 & 1.7 & -3.6 & 5.2 \\
\hline Age 55-59 × year2013-14 & -2.0 & 2.0 & 0.0 & 4.1 & 0.9 & 1.7 & 2.7 & 4.7 \\
\hline Age60-65 & 2.2 & 1.0 & 3.8 & 1.9 & -2.5 & 1.2 & -2.3 & 2.3 \\
\hline Aged60-65 × year2007-8 & -1.3 & 1.7 & -2.0 & 3.0 & -0.2 & 1.6 & 6.8 & 3.7 \\
\hline Aged60-65 × year2013-14 & -0.4 & 1.9 & 7.9 & 5.0 & 4.6 & 1.8 & 3.7 & 4.6 \\
\hline
\end{tabular}

Notes: Long-term unemployment is measured as cumulated duration of unemployment since the age of 15 years. AME refer to the expectation of this variable in month (including zero durations) and are derived from tobit models that account for the large share of people with zero durations in the sample; standard errors (se) are clustered to account for the panel structure of data The tobit models are estimated separately by gender and region on pooled data for the years 2000/01, 2007/08, and 2013/14 and include dummy variables for an individual's education/vocational qualification, health status, nationality, marital status, children (younger than 7 and 14 years, respectively), and other household income and its square

Source: Own calculations based on SOEP data 2000-2014

Point estimates of marginal effects indicate that long-term unemployment may have increased even more for people in the oldest age group especially in east Germany, but except for west German women aged 60-65 years these effects are statistically not significant. Estimated time effects for the age group 54-59 years are also statistically insignificant for all groups.

Although it is unclear to what extent long-term unemployment has increased above average among older workers, they have not fared better in this respect than younger people. Thus, the development of long-term unemployment in the observation period suggests a less favorable labor market situation of older people than the employment and traditional unemployment indicators suggest. A possible reason for this development may be related to reduced opportunities for early retirement discussed next.

\section{Early retirement}

As described in Sect. 2 regulations for early retirement between 60 and the legal retirement age of 65 years have become considerably more restrictive since the late 1990's. Early full retirement before the age of 60 years has always been restricted formally to so-called disability pensions, although the criteria for such a pension have also been changing over time. However, extended entitlement periods in the unemployment compensation system functioned as a bridge into early retirement until the labor reforms in 2005-6 changed this.

Table 5 reports AME (in percentage points) of age group and year interactions on the retirement probability and their standard errors. AME are derived from logit models esti- mated on the pooled sample of people aged 55 years and older for the years 2000-01 to 2013-14. People younger than 55 years are excluded from the following analysis because for them early retirement has always only been possible in case of disability. Except for the dummy variables for the presence of children in the household and the exclusion of pension income from other household income, the same control variables are included as in the unemployment logit models.

While retirement probabilities of people aged 55-59 years did not change significantly for men and for women in west Germany over the whole observation period, the average retirement probability of east German women in this age group declined by about 10 percentage points. Starting from a much higher level, the retirement rate of east German women in the oldest age group has declined by almost 25 percentage points by 2013-14 reducing this group's average retirement probability to a level comparable to that observed for west German women of this age group (see Table 7).

For people aged 60-65 years, average retirement probabilities dropped for all groups in the observation period. In east Germany, the drop in this age group amounted to almost $25 \%$ points for women and about 20 percentage points for men. In west Germany, average retirement probabilities of both men and women in the oldest age group declined by about 10 percentage points. Given the differences in the level of average retirement probabilities between men and women in the two regions in 2000-1, the AME reported in Table 5 imply that average retirement probabilities of people aged 60-65 years have converged to a similar level of about $30 \%$ by the end of the observation period. 
Table 5 Retirement probabilities 2000-2014, average marginal effects

\begin{tabular}{|c|c|c|c|c|c|c|c|c|}
\hline & \multicolumn{4}{|l|}{ Men } & \multicolumn{4}{|c|}{ Women } \\
\hline & \multicolumn{2}{|c|}{ West Germany } & \multicolumn{2}{|c|}{ East Germany } & \multicolumn{2}{|c|}{ West Germany } & \multicolumn{2}{|c|}{ East Germany } \\
\hline & AME & se & AME & se & AME & $\mathrm{se}$ & AME & se \\
\hline Year2007-8 & 0.8 & 3.5 & 1.0 & 6.4 & 5.8 & 3.9 & -5.6 & 5.6 \\
\hline Year2013-14 & -3.7 & 3.1 & -1.3 & 5.9 & 2.8 & 4.3 & -9.7 & 4.7 \\
\hline Age60-65 & 29.4 & 2.2 & 34.3 & 4.3 & 31.8 & 2.9 & 39.4 & 3.2 \\
\hline Aged60-65 × year2007-8 & -8.1 & 4.0 & -5.0 & 7.2 & -9.3 & 4.3 & -3.7 & 6.4 \\
\hline Aged60-65 × year2013-14 & -10.0 & 3.5 & -16.8 & 6.6 & -11.4 & 4.5 & -13.6 & 5.3 \\
\hline
\end{tabular}

Notes: AME - marginal effect on probability (in percent) from pooled logit estimates for the years 2000/01, 2007/08, and 2013/14 on the subsample of people aged older than 54 years; standard errors (se) are clustered to account for the panel structure of the SOEP estimation sample. The probability models are estimated separately by gender and region and include dummies for health status, nationality, marital status, children, and other household income and its square as additional control variables

Source: Own calculations based on SOEP data 2000-2014

\section{Real hourly wages}

Increasing earnings and wage inequality has been a very important topic in academic and policy discussions of recent labor market developments in Germany over the last decade or so, although relatively little seems to be known about how older workers have been affected by these developments. The substantial employment increase among older workers in recent years may be associated with a lower average wage growth among this group because people with a relatively low level of productivity who would previously have withdrawn from the labor force by becoming unemployed or by early retirement remain employed. Alternatively, the productivity of people at a given age may have changed over time due to changes in the level of skills, health and demographic structure. Here I focus on age effects on the change of hourly wages in the period 2000-2014 and control for these factors and potential selection effects with respect to employment. The self-employed are excluded from the analysis here because the difficulty to properly measure labor income on an hourly basis for them.

I measure hourly wages by dividing individual labor earnings per year by the number of annual hours worked by the same individual based on the SOEP generated earnings and hours variables. ${ }^{8}$ I use real hourly wages for the following analysis to abstract from overall changes in the overall level of wages over time (inflation). Nominal hourly wages are deflated by the consumer price index for all Germany. I apply the same approach as in the previous sections and identify age effects by regressing the log of real hourly wages on age and time dummies, interaction effects be-

\footnotetext{
8 An alternative wage measures can be constructed in the SOEP from information on current monthly labor income and the number of weekly hours actually worked in the reference month. As it turned out, estimation results reported below change little if this wage measure is used instead the one defined in the text.
}

tween age and time effects, and the usual control variables. These include dummy variables for an individual's level of education/vocational qualification, health status, and nationality. As a relatively large share of people, especially in the older age groups, have not worked in the reference period, and no wage can therefore constructed for them, I estimate selectivity-corrected OLS wage regressions on the subsample of employed people. Following the standard approach in the estimation of wage regressions, I derive the selection-correction term in these regressions from a firststage employment probit model with other household income than the individual's labor income (and its square) and dummy variables for marital status, and the number of (small) children in the household as exclusion restrictions.

AME derived from these regressions, which give the percentage change of the wage to a discrete change in the respective variable, and their standard errors are reported in Table 6. These wage effects are conditional on employment status and account for selection effects. For all groups, the selection term in the wage regressions is statistically significant indicating that the wage distributions of employed and non-employed people differ even after controlling for an individual's age, ecudational/vocational qualification, health status and nationality.

While real wages of the younger age group have, on average, not changed significantly in west Germany in the observation period, average real wages of this age group have increased by about $10 \%$ for men and fallen by more than $6 \%$ for women in east Germany between 2000-01 and 2013-14. For older men, real wages declined substantially in west Germany, and in the oldest age group also in east Germany, where these changes mainly took place since 2007-8. For women aged 60-65 years point estimates of AME indicate that real wages increased in west Germany and did not change in the observation period, but these effects are statistically not well determined (large standard errors), which is also the case for women aged 55-59 years in both regions. 
Table 6 Real hourly wages, average marginal effects

\begin{tabular}{|c|c|c|c|c|c|c|c|c|}
\hline & \multicolumn{4}{|l|}{ Men } & \multicolumn{4}{|c|}{ Women } \\
\hline & \multicolumn{2}{|c|}{ West Germany } & \multicolumn{2}{|c|}{ East Germany } & \multicolumn{2}{|c|}{ West Germany } & \multicolumn{2}{|c|}{ East Germany } \\
\hline & AME & se & AME & se & AME & se & AME & se \\
\hline Year2007-8 & -2.6 & 1.3 & 4.6 & 2.7 & -1.4 & 1.5 & -5.9 & 2.7 \\
\hline Year2013-14 & 1.0 & 1.5 & 10.4 & 2.8 & 0.3 & 1.7 & -6.6 & 2.9 \\
\hline Age55-59 & 35.5 & 3.1 & 18.4 & 4.7 & 15.7 & 3.4 & 14.3 & 4.9 \\
\hline Age $55-59 \times$ year $2007-8$ & -12.9 & 4.8 & 1.3 & 8.1 & -9.2 & 5.0 & 8.6 & 8.3 \\
\hline Age 55-59 × year2013-14 & -11.1 & 4.1 & -11.9 & 7.1 & -7.6 & 4.4 & 4.9 & 7.4 \\
\hline Age60-65 & 60.9 & 5.4 & 53.3 & 9.9 & 0.8 & 5.1 & 38.4 & 11.8 \\
\hline Aged60-65 × year2007-8 & -1.3 & 5.4 & 6.3 & 11.5 & 11.6 & 6.5 & -12.6 & 17.8 \\
\hline Aged60-65 × year2013-14 & -24.5 & 6.2 & -27.4 & 9.7 & 11.2 & 5.9 & 6.5 & 12.7 \\
\hline
\end{tabular}

Notes: The dependent variable is the log of the real hourly wage; wages below $1.5 €$ and above $150 €$ are excluded, nominal hourly wages are deflated by the CPI; AME - marginal effect gives the percentage change of the real hourly wage of employed people (conditional expectation of wages, given employment) derived from pooled OLS regressions with sample-correction for employment status for the years 2000/01, 2007/08, and 2013/14; standard errors (se) are clustered to account for the panel structure of the SOEP estimation sample. The wage regressions are estimated separately by gender and region include dummies for an individual's educational/vocational qualification, health status and nationality as additional control variables and. The first-stage probit employment equation includes as exclusion restrictions dummies for marital status, children, and other household income and its square

Source: Own calculations based on SOEP data 2000-2014

\section{Summary and implications for labor market policy}

The descriptive analysis of this paper has identified important differences in labor market trends for younger and older people, and among the latter also between people in the age groups 55-59 and 60-64 years, after statistically controlling for other determinants of labor market outcomes, such as an individual's level of educational/vocational qualification, health status, nationality, marital status and other factors measured at the household level. Detailed estimation results do not support simple generalizations regarding age effects on changes in labor market outcomes. In general, estimation results show that, although labor market outcomes still differ significantly between east and west Germany, and within region by gender, employment and unemployment rates of older workers seem to have converged, on average, between the two regions.

Estimation results for the various labor market indicators analyzed in this paper yield a number of important insights: While full-time employment rates of younger people have been declining or stagnating between 2000 and 2014, those of older people have been increasing dramatically among both men and women and in both regions, especially for people aged 60-65 years, where most of this increase occurred in the period after the economic crises in 2009. Furthermore, except for men in east Germany, part-time employment in the oldest age group also increased strongly in this period. Changes in unemployment rates differ substantially across age groups and by gender and region. While unemployment rates of people aged between 55-59 years declined in all groups between 2000 and 2014, unemploy- ment rates of people in the oldest age groups remained more or less constant in west Germany but substantially increased especially for women living in east Germany whose unemployment rate was relatively low at the beginning of the period. Thus, at least within regions there is convergence in unemployment rates across age groups. Long-term unemployment, measured as the cumulated duration of previous unemployment, increased for all groups in the observation period, with a particularly strong increase among east German men in the oldest age group. This increase in long-term unemployment may be related to the drop in this group's retirement probability, although substantial reductions in this probability are also estimated for the other groups for whom long-term unemployment increased much less. Finally, estimation results from selectivity-corrected wage regressions show that real hourly wages of men in the oldest age group declined substantially relative to those of younger men in both east and west Germany, where most of this decline took place after the recession. While real hourly wages of women seem to have not changed significantly in west Germany and to have declined in east Germany, differential effects for the older age could not be estimated with reasonable precision.

While knowledge of these facts may be important for the effective targeting of future labor market policies for older workers, conclusions about the potential effects of the labor market and pension policies that became effective in the observation period are probably more controversial. As described above, most indicators of labor market outcomes have improved dramatically, especially for the oldest age group both in absolute terms and relative to younger people. It seems unlikely that labor market and pension 
policies alone can explain these large effects. In particular, it is unlikely that the weak development of hourly real wages, which might have contributed to increasing employment among older workers, is mainly due to the labor market policies implemented in the observation period. Furthermore, estimated age effects vary by gender and region in a way that is difficult to link to the targeting of labor market and pension reforms that became effective in the observation period. Most of these policies are closely interrelated and may have affected older people of different birth cohorts quite differently. Thus, the identification of the "causal" effects of the policy reforms implemented in the observation period on labor market outcomes of older people would require very strong and untestable assumptions and is not attempted here.

Acknowledgements I want to thank Ulrich Walwei, Regina Riphahn and two anonymous referees for helpful comments on an earlier version of this paper.

Open Access This article is distributed under the terms of the Creative Commons Attribution 4.0 International License (http:// creativecommons.org/licenses/by/4.0/), which permits unrestricted use, distribution, and reproduction in any medium, provided you give appropriate credit to the original author(s) and the source, provide a link to the Creative Commons license, and indicate if changes were made. 


\section{Appendix}

Table 7 Means of labor market indicators for the reference age group 25-54 years in 2000-01

\begin{tabular}{lcccc}
\hline & Men & & Women & \\
& West Germany & East Germany & West Germany & East Germany \\
\hline Full-time employment (\%) & 81.5 & 74.4 & 33.0 & 48.4 \\
Part-time employment (\%) & 10.1 & 9.6 & 37.3 & 25.1 \\
Unemployment (\%) & 4.8 & 12.9 & 4.9 & 15.7 \\
Cumul. Unempl. Duration (years) & 1.9 & 1.8 & 1.7 & 2.5 \\
Retired (54 < age <60 yrs., \%) & 8.1 & 9.6 & 6.0 & 15.9 \\
Real hourly wage (Euro) & 19.0 & 12.1 & 14.1 & 11.6 \\
\hline
\end{tabular}

Notes: For definition of variables, see text

Source: Own calculations based on SOEP data 2000-01 


\section{References}

Ammermüller, A., Boockmann, B., Maier, M., Zwick, T.: Eingliederungszuschüsse und Entgeltsicherung für Ältere - Analysen auf Basis natürlicher Experimente. Vierteljahrsh Wirtschaftsforsch 75(3), 49-66 (2006)

Arent, S., Nagl, W.: Unemployment compensation and wages: evidence from the German Hartz reforms. Jahrb Nationialökon Stat 233(4), 450-466 (2013)

Börsch-Supan, A., Berkel, B.: Pension reform in Germany: the impact on retirement decisions. Finanzarchiv 60(3), 393-421 (2004)

Caliendo, M., Steiner, V.: Aktive Arbeitsmarktpolitik in Deutschland: Bestandsaufnahme der mikroökonomischen Evaluationsforschung und kritische Bewertung. Z Arbeitsmarktforsch 38(2/3), 386-418 (2005)

Dietz, M., Walwei, U.: Germany - no country for old workers? J Labor Mark Res 44, 363-376 (2011)

Dietz, M., Koch, S., Krug, G., Stephan, G.: Die Entgeltsicherung für Ältere: ein Auslaufmodell? WSI Mitt 2011(5), 226-233 (2011)

Dlugosz, S., Stephan, G., Wilke, R.A.: Fixing the leak: Unemployment incidence before and after the 2006 reform of unemployment benefits in Germany. Ger Econ Rev 15(3), 329-352 (2014)

Fitzenberger, B., Wilke, R.A.: Unemployment durations in West-Germany before and after the reform of the unemployment compensation system during the 1980s. Ger Econ Rev 11(3), 336-366 (2010)

Fitzenberger, B.: Nach der Reform ist vor der Reform? Eine arbeitsökonomische Analyse ausgewählter Aspekte der Hartz-Reformen. In: Schulze, G.G. (ed.) Reformen für Deutschland. Die wichtigsten Handlungsfelder aus ökonomischer Sicht, pp. 49-78. Schäffer-Poeschel, Stuttgart (2009)

Hanel, B.: The effect of disability pension incentives on early retirement decisions. Labour Econ 19(4), 595-607 (2012)

Jahn, E., Walwei, U.: Reform in Trippelschritten oder besser mit großem Sprung? IAB Kurzbericht 21/2003. (2003)

Ludsteck, J., Seth, S.: Comment on "unemployment compensation and wages: evidence from the German Hartz reforms by Stefan Arent and Wolfgang Nagl. Jahrb Nationialökon Stat 234(5), 635-644 (2014)
Möller, J., Hutter, C.: The effecs of age, skill and sector composition on the wage inequality in Germany. In: Genser, B., Ramser, H.-J., Stadler, M. (eds.) Umverteilung und soziale Gerechtigkeit Wirtschaftswissenschaftliches Seminar Ottobeuren 40. Mohr Siebeck, Tübingen. (2011)

Ruppe, K., Stephan, G.: Länger im Betrieb und gleicher Lohn. IAB Kurzbericht 25/2009. (2009)

Steiner, V.: Extended benefit-entitlement periods and the duration of unemployment in West Germany. ZEW-Discussion Paper., pp 97-14 (1997)

Steiner, V., Schmitz, H.: Benefit-entitlement effects and the duration of unemployment an ex-ante evaluation of recent labour market reforms in Germany. Discussion Paper 678. DIW, Berlin (2007)

Steiner, V., Wrohlich, K.: Work incentives and labor supply effects of the 'mini-jobs reform' in Germany. Empirica 32, 91-116 (2005)

Steiner, V.: Beschäftigungsförderung und Einkommenssicherung im Niedriglohnbereich - Wege und Irrwege. In: Schulze, G.G. (ed.) Reformen für Deutschland. Die wichtigsten Handlungsfelder aus ökonomischer Sicht, pp. 49-78. Schäffer-Poeschel, Stuttgart (2009)

Toft, C., Whitehouse, E.: Retirement policy and the transformation of the labour market for older workers in the European Union and the United States. Unpublished (2017)

Wolff, J., Stephan, G.: Subsidized work before and after the German Hartz reforms: design of major schemes, evaluation results and lessons learnt. Iza J Labor Policy 2, 16 (2013)

Viktor Steiner has been Professor of Economics at the Free University of Berlin since 2002. He received his $\mathrm{PhD}$ in Economics from the University of Linz, Austria and his Habilitation in Economics and Econometrics from the University of Frankfurt/Main. His previous positons include: Director of the Public Economics Department at DIW Berlin, Professor of Economics at the Center for Economic Studies (CES) at the University of Munich and Research Director at the ifo Institute for Economic Research, and Head of Department "Labour Economics and Social Policy" at the Centre for European Economic Research (ZEW) in Mannheim, Germany. His research interests are in the field of empirical public and labor economics, in particular the evaluation of fiscal and social policies. 